\title{
CONSTITUTIONAL LAW: RESOLVING CONFLICT BETWEEN THE RIGHT TO TRAVEL AND IMPLEMENTATION OF FOREIGN POLICY
}

The Supreme Court upheld an areal restriction on travel to Cuba when the passport applicant's purpose was to gather information. The Court pursued a due process inquiry and held the first amendment inapposite in this situation. The Court refused to recognize incidental involvement of peripheral first amendment freedoms and afforded questionable future constitutional protection for the right to travel abroad.

$\mathrm{T}$ HE FEDERAL COURTS have frequently been asked to reconcile the conflict between an individual citizen's right to travel abroad and the Government's interest in restricting such travel in order to effect a sound foreign policy. ${ }^{1}$ In the most recent case, Zemel $v$. Rusk, ${ }^{2}$ the Supreme Court upheld a geographic passport restriction on travel to Cuba. However, the Court did not clearly

1 Aptheker v. Secretary of State, 378 U.S. 500 (1964) (striking down passport denials to two ranking Communist Party officials); Kent v. Dulles, 357 U.S. 116 (1958) (overruling denial of passports to a citizen based entirely on his political beliefs); Worthy v. United States, 328 F.2d 386 (5th Cir. 1964) (reversing conviction of a citizen for entering the United States without a valid passport); Porter v. Herter, 278 F.2d 280 (D.C. Cir.) (per curiam), cert. denied, 364 U.S. 837 (1960) (upholding denial of passport to congressman for travel to geographically restricted Communist China); Worthy v. Herter, 270 F.2d 905 (D.C. Cir.), cert. denied, 361 U.S. 918 (1959) (upholding the right of the Department of State to impose area restrictions); Frank v. Herter, 269 F.2d 245 (D.C. Cir.), cert. denied, 361 U.S. 918 (1959) (upholding geographic restriction banning all American travel to Communist China); Briehl v. Dulles, 248 F.2d 561 (D.C. Cir. 1957), rev'd sub nom. Kent v. Dulles, supra (reversing passport denial because of political beliefs); Shachtman v. Dulles, 225 F.2d 938 (D.C. Cir. 1955) (ruling that one cannot be denied a passport merely because of his political associations); MacEwan v. Rusk, 228 F. Supp. 306 (E.D. Pa. 1964), aff'd per curiam, 344 F.2d 963 (3d Cir. 1965) (upholding areal passport restriction imposed on Cuba); Copeland v. Secretary of State, 226 F. Supp. 20 (S.D.N.Y.), vacated and remanded, 378 U.S. 588 (1964) (sustaining the right of a passport applicant to refuse to execute a non-communist affidavit); Mayer v. Rusk, 224 F. Supp. 929 (D.D.C. 1963), vacated and remanded, 378 U.S. 579 (1964) (sustaining a passport applicant's refusal to divulge information regarding his communist affiliation); Flynn v. Rusk, 219 F. Supp. 709 (D.D.C. 1963), rev'd sub nom. Aptheker v. Secretary of State, supra; Dayton v. Dulles, 146 F. Supp. 876 (D.D.C. 1956), aff'd, 254 F.2d 71 (D.C. Cir. 1957), rev'd, 357 U.S. 144 (1958) (reversing passport denial based on political affiliations); Boudin v. Dulles, $136 \mathrm{~F}$. Supp. 218 (D.D.C. 1955), aff'd, 235 F.2d 532 (D.C. Cir. 1956) (overruling passport limitation based on classified information garnered from unrevealed sources); Bauer v. Acheson, 106 F. Supp. 445 (D.D.C. 1952) (reversing passport denial when there was no opportunity to contest denial).

2381 U.S. 1 (1965). 
indicate how future passport cases will be analyzed, and it refused to determine the constitutionality of criminal sanctions presently available to regulate travel abroad.

In 1961, the Department of State, acting under the authority of a Presidential order ${ }^{3}$ issued pursuant to the Passport Act of 1926,4 imposed a ban on American travel to $\mathrm{Cuba}^{5}$ and announced that specific approval of the Secretary of State would be required to obtain exemption from the prohibition. ${ }^{6}$ Thereafter, Zemel applied to the Department of State to have his existing passport validated for travel to Cuba. On the ground that his declared purpose, to gather information, ${ }^{7}$ did not meet the established standard for granting exceptions, ${ }^{8}$ the Department denied the request. He then unsuccessfully sought declaratory relief in a federal district court, al-

${ }^{3}$ " $\$ 124$. The Secretary of State is authorized in his discretion to refuse to issuc a passport, to restrict a passport for use only in certain countries, to restrict it against use in certain countries, to withdraw or cancel a passport already issued, and to with. draw a passport for the purpose of restricting its validity or use in certain countries.

" $\$ 125$. Should a person to whom a passport has been issued knowingly use or attempt to use it in violation of the conditions or restrictions contained thercin or of the provisions of these rules, the protection of the United States may be withdrawn from him while he continues to reside abroad.

" $\$ 126$. The Secretary of State is authorized to make regulations on the subject of issuing, renewing, extending, amending, restricting, or withdrawing passports additional to these rules and not inconsistent therewith." Exec. Order No. 7856, 3 Fed. Reg. 687 (1938). This order on its face purports to allow the Government to withdraw its protection from a citizen merely because he misuses or attempts to misuse his passport. It is arguable, however, that procedural and substantive safeguards would have to be present before a citizen could be denied protection by the Government. Cf. Wilson v. Girard, 354 U.S. 524 (1957); Hearings on the Right to Travel Before the Subcommittee on Constitutional Rights of the Senate Committee on the Judiciary, 85th Cong., 1st Sess., pt. 1, at 86-87 (1957) [hereinafter cited as Hearings on the Right to Travel]; notes 15 and 16 infra. Furthermore, the order appears inconsistent with 15 Stat. 224 (1868), 22 U.S.C. $\$ 1732$ (1964), which provides that the President shall use whatever necessary means short of war to effect release of any American citizen wrongly deprived of his freedom by a foreign government.

Section 1 of the Passport Act provides that "the Secretary of State may grant and issue passports ... under such rules as the President shall designate and prescribe for and on behalf of the United States . ..." 44 Stat. 887, 22 U.S.C. § 21la (1964).

'Public Notice 179, 26 Fed. Reg. 492 (1961).

Ibid.

"Zemel stated that the "purpose of the proposed trip was 'to satisfy my curiosity about the state of affairs in Cuba and to make me a better informed citizen.' " 381 U.S. at 4. Thus, he sought to have his passport validated for travel to Cuba and to have the Government enjoined from interfering with that travel by enforcing the relevant regulations and criminal sanctions. Ibid.

${ }^{8}$ In a companion press release to the announcement of the restriction, the Department stated that it anticipated granting exceptions to those "persons whose travel may be regarded as being in the best interests of the United States, such as newsmen or businessmen with previously established business interests." Department of State Press Release No. 24, Jan. 16, 1961. 
leging that the Passport Act and the restriction on Cuban travel were unconstitutional. ${ }^{2}$ The United States Supreme Court affirmed the judgment of the lower federal court. ${ }^{10}$ It held that administrative practices of the Department of State under the 1926 act $^{11}$ and its predecessors ${ }^{12}$ were incorporated into the act, thus providing sufficient guidelines to define the scope of delegated legislative power and overcome the constitutional objections of overbreadth and separation of powers. ${ }^{13}$ The Court similarly held, under a due process inquiry, that the areal restriction was commensurate with the legitimate government need therefor and thus was a reasonable limitation on the constitutional right to travel. ${ }^{14}$

The initial passport cases established a due process requirement that both procedural ${ }^{15}$ and substantive ${ }^{16}$ safeguards be present when-

- Zemel interposed a number of constitutional contentions. In particular, he claimed that the Passport Act was an unconstitutional delegation of legislative authorization for imposition of area restrictions. He further asserted that denial of a passport violated his first and fifth amendment rights. He also contended that $\$ 215$ of the Immigration and Nationality Act of 1952, 66 Stat. 190, 8 U.S.C. $§ 1185$ (1964), which requires citizens to have passports when leaving or entering the United States in time of war or national emergency, was unconstitutional. 381 U.S. at 4. Section 215 is presently in effect, having been activated by Presidential Proclamation No. 3004, Jan. 17, 1953, 67 Stat. C31, which declared the existence of a national emergency.

10381 U.S. 1 (1965), affirming 228 F. Supp. 65 (C.D. Conn. 1964). Accord, MacEwan v. Rusk, 228 F. Supp. 306 (E.D. Pa. 1964), aff'd per curiam, 344 F.2d 963 (3d Cir. 1965), in which the geographic restriction on travel to Cuba was also upheld.

${ }^{11}$ Passport Act, 44 Stat. 887 (1926), 22 U.S.C. \$ 211 a (1964).

22 The original federal legislation dealing with issuance and control of passports was the Act of Aug. 18, 1856, ch. 127, $\S 23,11$ Stat. 52. This statute has been repeatedly reenacted without significant alteration; in fact, the language of the Passport Act of 1926 is almost identical to that of the 1856 act.

23381 U.S. at 17-18. See note 49 infra and accompanying text.

16 Overly simplified, a due process inquiry in this area normally entails determining and assessing the governmental need for promulgating the regulation. If that purpose is meritorious and if the provision is reasonably adapted to accomplishing the objective, the measure will be upheld. See, e.g., Whitney v. California, 274 U.S. 357, $371-72$ (1927).

In Zemel, the Court stated that "the requirements of due process are a function not only of the extent of the governmental restriction imposed, but also of the extent of the necessity for the restriction." 381 U.S. at 14. The Court then examined the necessity for the restriction in light of the gravity of the communist threat from Cuba and held that the travel ban was reasonable by noting that "the restriction which is challenged in this case is supported by the weightiest considerations of national security [and this fact] is perhaps best pointed up by recalling that the Cuban missile crisis of October 1962 preceded the filing of appellant's complaint by less than two months." Id. at 16.

15 Bauer v. Acheson, 106 F. Supp. 445 (D.D.C. 1952), was the first case to disallow a passport restriction on the basis that the applicant had been denied procedural due process guaranteed by the fifth amendment. In Bauer, the Secretary of State revoked the passport of a former government employee while she was traveling in France. The only reason advanced was that such cancellation would be in the best 
ever the Government seeks to deny, limit or revoke a passport. Following these early cases, the courts expanded the scope of substantive safeguards protecting an individual from passport restrictions. In Kent $v$. Dulles, ${ }^{17}$ the Supreme Court held that the 1926 act acquired its meaning from past passport practices and supported denial of a passport solely on the basis of the applicant's political beliefs only when he lacked citizenship or allegiance to the United States or participated in unlawful conduct. ${ }^{18}$ The Court also confirmed what prior cases had implied by holding that "the right to travel is a part of the 'liberty' of which the citizen cannot be deprived without due process of law under the Fifth Amendment."19

Six years later, in Aptheker $v$. Secretary of State, ${ }^{20}$ the Supreme Court again was asked to decide if the Department of State could deny a passport to an individual because of his political beliefs and associations. The Court responded by striking down as void on its face a statute ${ }^{21}$ making it unlawful for a member of a registered communist organization ${ }^{22}$ to apply for, use or attempt to use a

interests of the United States. The court held that "revocation of the plaintiff's passport without notice and hearing before revocation, as well as refusal to renew such passport without an opportunity to be heard, was without authority of law." Id. at 452. This case and subsequent cases have established that the Department must at least apprise a citizen why his passport was restricted and afford him an opportunity for review. See, e.g., Boudin v. Dulles, 136 F. Supp. 218 (D.D.C. 1955), aff'd, 235 F.2d 532 (D.C. Cir. 1956). Shortly after the Bauer decision the Department established a Board of Passport Appeals to allow an applicant to appeal adverse administrative rulings by passport officials. Act of July 18, 1956, 70 Stat. 563, 5 U.S.C. 151 (c) (1964).

I0 The first case to establish affrmatively that sufficient legal grounds must exist before a passport can be denied or restricted was Shachtman v. Dulles, 225 F.2d 938 (D.C. Cir. 1955). The applicant was chairman of an organization which had been classified by the Attorney General as subversive and communistic. Although in re. viewing his passport application for travel to Europe, the Department of State found that the organization had "no connection with the Communist International and was hostile thereto," it still denied his request on the basis that issuance of the passport "would be contrary to the best interests of the United States." Id. at 942. The court held that the Department had asserted an insufficient basis for the passport denial.

Whether substantive due process was observed has been the basic question litigated in most of the passport cases cited in note 1 supra. As to what constitutes such due process, see Gould, The Right to Travel and National Security, 1961 WASH. U.L.Q. 334; Jaffe, The Right to Travel: The Passport Problem, 35 Foreign AFFairs 17 (1956). 17357 U.S. 116 (1958).

${ }^{18} \mathrm{Id}$. at 127. Thus, the Court deemed the applicant's affiliation with the Communist Party insufficient as a basis for denying him a passport. Id. at 130 .

${ }^{10} \mathrm{Id}$. at 125 .

20378 U.S. 500 (1964).

${ }^{21}$ Subversive Activities Control Act of 1950, ch. 1024, § 6, 64 Stat. 993.

22 Registration of communist-associated organizations had been ordered under the authority of the Subversive Activities Control Act of 1950, ch. 1024, § 7, 64 Stat. 993. 
passport. The Court relied on first amendment cases ${ }^{23}$ as authority and concluded that the travel restriction "sweeps too widely and too indiscriminately across the liberty guaranteed in the Fifth Amendment."24 Thus, the Court based its decision on a finding that there had been a violation of substantive due process, but it combined first and fifth amendment standards in doing so and implied that limiting the right to travel involves "peripheral" first amendment rights $^{25}$ as well as a fifth amendment guarantee. ${ }^{26}$

${ }^{23}$ NAACP v. Button, 371 U.S. 415 (1963); Shelton v. Tucker, 364 U.S. 479 (1960); Thornhill v. Alabama, 310 U.S. 88 (1940).

Writing for a minority of three, Mr. Justice Clark gave short shrift to the contention that limiting the right to travel involves first amendment questions. He argued that the cases relied upon by the majority were "not apposite here," for they involved first amendment problems and the majority's holding was based solely on "the Fifth Amendment's guarantee of the right to travel abroad." 378 U.S. at 523.

${ }^{24} I d$. at 514. The context of this statement is most significant. Continuing, the Court stated that "the prohibition against travel is supported only by a tenuous relationship between the bare fact of organizational membership and the activity Congress sought to proscribe. The broad and enveloping prohibition indiscriminately excludes plainly relevant considerations such as the individual's knowledge, activity, commitment, and purposes in and places for travel." Ibid. Thus, the Court combined the normal first amendment problem of overbreadth with the substantive due process objection of insufficient nexus between the restriction and the governmental need asserted and held that the limitation was not reasonable.

${ }_{25}$ The term "peripheral first amendment right" is normally applied to a freedom which receives some protection under the first amendment but is not literally enumerated in the amendment itself. For example, the term "speech-plus" has been applied to expression which is not pristine speech but is accompanied by some form of conduct. See NAACP v. Button, 371 U.S. 415 (1963).

Applying this concept to Zemel, Mr. Justice Goldberg, dissenting, said that "the right to travel is at the periphery of the First Amendment, rather than at its core, largely because travel is, of course, more than speech: it is speech brigaded with conduct." 381 U.S. at 26 (dissenting opinion).

There are differing views concerning what judicial procedure should be followed in analyzing peripheral first amendment cases. See, e.g., Konigsberg v. State Bar, 366 U.S. 36 (1961); Barenblatt v. United States, 360 U.S. 109 (1959). Basically, the process followed consists of defining the right involved, ascertaining its relative position in the spectrum of first amendment protection, determining the extent of infringement, and examining the reasons for the abridgment. Ibid. Whether all these steps are needed, which inquiries should be emphasized, and whether results from different steps should be compared with each other are questions which presently divide the Court. See ibid.

For more complete discussions of judicial approaches to first amendment controversies, and of balancing of interests in particular, see Emerson, Toward a General Theory of the First Amendment, 72 YALE L.J. 877 (1963); Kalvern, The New York Times Case: A Note on "The Central Meaning of the First Amendment," 1964 SuP. Cr. REv. 191, 213-218.

${ }^{26} 378$ U.S. at 514. See note 24 supra. The Court stated that the right to travel is a constitutional freedom "closely related to rights of free speech and association." 378 U.S. at 517. The Court implied that travel abroad can incidentally involve enjoyment of first amendment guarantees to such an extent that it will receive some protection under that amendment. Ibid. See also id. at 519-20 (Douglas, J., concurring). 
Zemel accorded the Court a further opportunity to examine this recurrent problem of whether abridgment of a particular incident to the right to travel ${ }^{27}$ involves first or fifth amendment considerations, or a combination of both. ${ }^{28}$ Moreover, the case presented a relatively new inquiry. While in prior cases the Court had sharply proscribed imposition of passport restrictions based on the political beliefs and associations of an individual applicant, it had not conclusively decided whether a restriction forbidding travel to a given foreign area could be imposed upon all citizens. ${ }^{29}$

In Zemel, the majority concluded that restriction of travel having as its express purpose gathering of information did not involve a first amendment right. ${ }^{30}$ By doing so, it rejected Zemel's first amendment argument $t^{31}$ and implicitly held that the abridgment of the free flow of information was too incidental to warrant a peripheral first amendment or speech-plus inquiry. ${ }^{32}$ Instead the majority

${ }^{27}$ In Zemel, the incident to the right to travel was gathering information. See note 7 supra.

${ }^{28}$ In Kent, Aptheker and Zemel the Supreme Court stated that the right to travel is a fifth amendment liberty. 357 U.S. at 125; 378 U.S. at 514; 381 U.S. at 14. However, Court members disagreed when they considered whether the right is afforded any protection by the first amendment, due to its ability to enhance enjoyment of that amendment's freedoms. See notes 23,26 supra and note 32 infra.

${ }^{20}$ Previously, lower federal courts had upheld geographic restrictions in three cases, but the Supreme Court had refused to revicw their decisions. Porter v. Herter, 278 F.2d 280 (D.C. Cir.) (per curiam), cert. denied, 364 U.S. 837 (1960) (areal restriction on Communist China); Worthy v. Herter, 270 F.2d 905 (D.C. Cir.), cert. denied, 361 U.S. 918 (1959) (involving all the geographic restrictions then in effect); Frank v. Herter, 269 F.2d 245 (D.C. Cir.), cert. denied, 361 U.S. 918 (1959) (travel ban on Communist China). Sec also MacEwan v. Rusk, 228 F. Supp. 306 (E.D. Pa. 1964), aff'd per curiam, 344 F.2d 963 (3d Cir. 1965) (upholding the areal restriction on Cuba).

Currently, geographic restrictions are imposed upon Albania, Bulgaria, Cuba and the communist-controlled parts of China, Korea and Vietnam. 33 Der't STate Bull. 777 (1955). Historically, such restrictions have been placed on travel to areas quarantined for health purposes; areas in which there existed a state of belligerency or threatened belligerency; countries embroiled in political controversies involving the United States or American citizens; and areas under control of authorities with whom the United States did not have diplomatic relations. See Rauh and Pollitt, Restrictions on the Right to Travel, 13 WEs. REs. L. REv. 128, 132-40 (1961); Hearings Before the Senate Committee on Foreign Relations on Department of State Passport Policies, 85th Cong., Ist Sess., 63-69 (1957). The Government has advanced various reasons for these restrictions, but basically it has expressed concern for the safety of individual citizens traveling in these areas and a desire to "punish" the restricted country. Ibid.

30381 U.S. at 16.

${ }^{31}$ Zemel argued that the "travel ban is a direct interference with the first amend. ment rights of citizens to travel abroad so that they might acquaint themselves at first hand with the effects abroad of our Government's policies, foreign and domestic, and with conditions abroad which might affect such policies." "Ibid.

${ }^{32}$ See note 25 supra. The majority stated that "the Secretary's refusal to validate passports for Cuba renders less than wholly free the flow of information concerning 
held that the degree of first amendment involvement incidentally resulting from the travel ban was only "a factor to be considered in determining whether appellant has been denied due process of law." 33 This interpretation of the first amendment seems inconsistent with the Court's subsequent holding in Lamont v. Postmaster General. ${ }^{34}$ In Lamont, the Supreme Court struck down a statute requiring postal officials to detain and destroy communist political propaganda forwarded by unsealed mail from foreign countries unless the addressee returned a reply card to the officials indicating his desire to receive such mail..$^{35}$ In this case and previous cases, ${ }^{36}$

that country .... [But] to the extent that the Secretary's refusal to validate passports for Cuba acts as an inhibition (and it would be unrealistic to assume that it does not), it is an inhibition of action." 381 U.S. at 16. It analogized the incidental infringement on gathering information occasioned by the area restriction to the "decreased data fow" resulting from not permitting "unauthorized entry into the White House" and concluded that "the right to speak and publish does not carry with it the unrestrained right to gather information." Id. at 17.

Zemel is not the only recent Supreme Court case to present both the dichotomy and the concomitant similitude between action and a first amendment freedom. The Court has repeatedly struggled with this problem and has attempted to establish guidelines outlining the scope of first amendment protection. See, e.g., Lamont v. Postmaster General, 381 U.S. 301 (1965); Cox v. Louisiana, No. 49, 379 U.S. 559 (1965); Cox v. Louisiana, No. 24, 379 U.S. 536 (1965). The resolution of this controversy in Zemel is reflected in the concurring opinion of Mr. Justice Brennan in Lamont, for he referred to Zemel as a case involving a restriction "only incidentally limiting ... [the] unfettered exercise" of free speech. Lamont v. Postmaster General, supra at 308.

Mr. Justice Douglas, however, took issue with this analysis. His Zemel dissent, concurred in by Mr. Justice Goldberg, emphasized the involvement of the first amendment in the travel restriction. He stressed the necessity for a mature, well-informed citizenry as a prerequisite to a strong national government and a peaceful world community. He reasoned that the right to travel helped to insure fulfillment of this need and therefore necessarily involved peripheral first amendment guarantees. 381 U.S. at 24. Utilizing a familiar first amendment test, Douglas found that the restriction on Cuba was overly broad, for it failed to meet the precise evil and thus constituted an invasion of protected freedoms. Id. at 25.

${ }^{33} I d$. at 16. The Court held Zemel distinguishable from Kent, and thus implicitly from Aptheker, in the degree of first amendment involvement present in the different situations. Ibid. Also, the Court emphasized the disparity between the restrictions in Kent, which were imposed because of some expression or association characteristic to the individual applicant, and the geographic restriction in Zemel imposed on the entire populace "because of foreign policy considerations affecting all citizens." Id. at 13 .

34 381 U.S. 301 (1965).

${ }^{38}$ The Court reasoned that the statute imposed an affirmative obligation which operated as a limitation on unfettered exercise of the addressee's first amendment rights and was therefore unconstitutional. The holding implied that to insure the free interchange of ideas envisioned by the first amendment, mere protection of an individual's right to distribute information is not sufficient. One has to gather knowledge in order to form his views, and he needs to have listeners and readers with whom to associate, converse and correspond in order to make the right of expression meaningful. This implication of the holding in Lamont is strengthened by the concurring opinion of Mr. Justice Brennan, in which Justices Goldberg and Harlan 
the Court has implied that the first amendment affords protection to a citizen to gather information and to inform himself about various political ideologies and the effects of his Government's policies so that he might better exercise rights and privileges of citizenship. Moreover, a procedure which involves considering traditional first amendment areas only as factors to be viewed within the spectrum of a reasonableness inquiry does not provide necessary standards for adequate constitutional predictability. ${ }^{37}$ Furthermore, it is questionable whether such an approach affords sufficient protection to an individual citizen's right to travel abroad and its attendant facilitation of first amendment freedoms.

Since questions of the degree of first amendment involvement and whether action ${ }^{38}$ or a peripheral first amendment right ${ }^{30}$ is affected are present in Zemel and will always be relevant in passport cases, perhaps an inquiry analogous to a speech-plus analysis ${ }^{10}$ would be preferable to the majority's due process examination. Such an approach would not rectify the need for constitutional predictability; but compared to the reasonableness criterion, it would permit a more inclusive, accurate weighing of the governmental need asserted and the other competing interests involved.41 Similarly, it would

joined. "It is true," he noted, "that the First Amendment contains no specific guarantee of access to publications. However, the protection of the Bill of Rights goes beyond the specific guarantees to protect from congressional abridgment those equally fundamental personal rights necessary to make the express guarantecs fully meaningful." Id. at 308.

${ }^{36}$ See, e.g., New York Times Co. v. Sullivan, 376 U.S. 255 (1964); Shelton v. Tucker, 364 U.S. 479 (1960); Yates v. United States, 354 U.S. 298 (1957).

${ }^{37}$ This criticism assumes that constitutional predictability in this area is a desirable goal. Arguably, this supposition can be justified by the foreigu policy needs of the Department to know what passport restrictions validly can be employed and the avoidance of resultant litigation each time a new restriction is imposed. However, another relevant consideration is the need for constitutional flexibility in the foreign relations area because of the unique exigencies characteristic to each situation.

${ }^{38}$ See note 32 supra.

${ }^{30}$ See notes 25,32 supra.

\$0 See note 25 supra.

\$1 This approach was advocated by Justices Douglas and Goldberg. They disagreed with the majority's interpretation of the extent to which first amendment questions had affected the decisions in Kent and Aptheker. 381 U.S. at 16 \& n.17. Goldberg and Douglas implied that those decisions afforded precedent for considering peripheral first amendment rights in Zemel. Id. at 23-26, 37-38.

However, the majority avoided this method of inquiry and left unanswered the question of how great a degree of first amendment involvement need he present beforc any first amendment inquiry will be pursued. Id. at 16. For example, in the area of freedom of religion suppose that American adherents of the Islam faith desire to travel to Mecca as a necessary exercise of their faith, but cannot obtain passports because Saudi Arabia has previously been geographically restricted. If confronted with 
occasion more thorough evaluation and protection of the interests involved in the conflict between the Government's need and the individual citizen's right. ${ }^{42}$ It would not necessarily lead to a different holding in passport cases; indeed, the majority might have employed it to uphold the travel limitation in Zemel. The restriction was not aimed directly at the right to gather information, as in Lamont. Rather, specific conduct of the citizen in gathering information was prohibited as a mere incident to the exercise of foreign relations powers to implement government policy. Also, avoidance of embarrassment to foreign policy objectives which might result from involvement of an American traveler in the Cuban political crisis ${ }^{43}$ and the declared need to isolate Cuba in order to avoid communist infiltration in the Western Hemisphere ${ }^{44}$ might justifiably warrant a restriction of the right to gather information. Further, the abridgment is not complete since under the State Department's order newsmen are permitted to travel to $\mathrm{Cuba}^{45}$ and thus can report information to allow a citizen to analyze the propriety of his Government's foreign policy there. ${ }^{46}$ Ironically, such an evaluation may have been utilized by the majority in applying the reasonableness standard of its due process inquiry. ${ }^{47}$

The Zemel decision also suggests other difficulties. The Court held that the validity of any restriction imposed upon foreign travel must be tested by an investigation to determine whether it is the

such a case, the Court may give a more expansive treatment to the first amendment issue, since a greater infringement upon a traditionally first amendment area is arguably involved.

12 Compare, e.g., Cox v. Louisiana, No. 49, 379 U.S. 559 (1965); Cox v. Louisiana, No. 24, 379 U.S. 536 (1965); Gibson v. Florida Legislative Investigation Comm., 372 U.S. 539 (1963); Konigsberg v. State Bar, 366 U.S. 36 (1961).

13 See note 53 infra.

" Because of the Castro government's explicit policy of infiltration the Organization of American States had adopted a resolution calling for isolation of Cuba. See N.Y. Times, July 4, 1963, p. 1, col. 5 .

"See note 8 supra.

${ }^{16}$ Zemel, however, might respond that such arguably censored information is inadequate for his purpose of ascertaining the true state of affairs in Cuba. Such an argument might then occasion consideration of whether the right to gather information, if such right is found to exist, entails a right to access from the best source, from a source that is reasonable under the circumstances, or from at least one source.

${ }^{6}$ See note 14 supra. The Zemel approach to passport restrictions was not new, for it was advocated by Mr. Justice Clark in speaking for the minority in Aptheker. Although the majority had considered freedom of association as a relevant factor in its analysis of the latter case, Clark would not concede first amendment involvement. He employed a due process inquiry and found that "the [passport] denial is reasonably related to the national security. The degree of restraint upon travel is outweighed by the dangers to our very existence." 278 U.S. at 527. 
type of restriction imposed by the Department of State prior to the passage of the Passport Act of 1926 and if, as such, it was adequately considered and thus tacitly incorporated by Congress into the broad powers delegated to the Executive under the act. ${ }^{48}$ Furthermore, the Court found congressional affirmance of the restriction by negative implication, for Congress did not explicitly forbid this type of restriction imposed under the Passport Act when it passed the Immigration and Nationality Act of 1952.40 However, legitimate divers conclusions can be drawn from the legislative history of a particular restriction, ${ }^{50}$ and in many circumstances the practical diffculty of investigating State Department procedure is obvious. ${ }^{51}$ The majority's methodology involves an exceedingly complicated inquiry and implies an ad hoc approach to passport restrictions, making each case largely dependent upon its factual setting and thus

${ }^{18}$ See the majority's examination of the history of geographic restrictions under the Passport Act and prior to it, 381 U.S. at 7-11.

${ }^{19}$ Id. at 11-12. The legislative and administrative history of the Passport Act was focal to the majority's consideration of Zemel's argument that the act was an unconstitutional delegation of unbridled legislative power to the Executive. Since the literal language of the statute contained insufficient standards to guide the Executive in imposing passport restrictions, see note 4 sttpra, a finding that Congress had incorporated administrative guidelines into the meaning of the act was requisite for the Court to sustain it as a broad, but constitutional, delegation of legislative authority. Thus the Court resorted to the legislative history, noting that "we have held ... [citing Kent] and reaffirm today, that the 1926 Act must take its content from history: it authorizes only those passport refusals and restrictions 'which it could fairly be argued were adopted by Congress in light of prior administrative practicc.'" 381 U.S. at 17-18.

Mr. Justice Goldberg agreed with the methodology of the majority, for he also analyzed the history of American passport practices. However, his dissent concluded that Congress could not have authorized peacetime areal restrictions by adopting the act, for in all but one "isolated" instance geographic restrictions wcre imposed in time of war on areas of belligerency. $I d$. at 36 .

The majority also attempted to justify the broad sweep of both the Passport Act and the travel ban by noting that "Congress-in giving the Executive authority over matters of foreign affairs-must of necessity paint with a brush broader than that it customarily wields in domestic areas." $I d$. at 17. Dissenting Justices Goldberg and Black rejected the theory, implicit in this statement, that the Executive has inherent authority to act in the passport area as an incident of his power to conduct foreign affairs. Id. at 20, 28-30 (dissenting opinion). Black analogized to Youngstown Sheet and Tube Co. v. Sawyer, 343 U.S. 579 (1952), and concluded that "regulation of passports, just like regulation of steel companies, is a law-making-not an executivc, law-enforcing-function." 381 U.S. at 21. He also refused to subscribe to the majority's view of the Passport Act, for he deemed it an invalid delegation of legislative authority "marked by no bounds except an unlimited discretion." Ibid.

${ }^{50}$ This fact is illustrated by the scholarly examinations and opposite conclusions reached by Mr. Chief Justice Warren and Mr. Justice Goldberg in the Zemel case. See also Briehl v. Dulles, 248 F.2d 561 (D.C. Cir. 1957).

${ }^{51}$ The difficulties of investigation are illustrated in Hearings on the Right to Travel. 
further curtailing adequate constitutional predictability. Deference to the Department's judgment as to what travel limitations are vital to implement the Government's foreign policy may be appropriate. ${ }^{52}$ However, such an approach further emphasizes the lack of adequate safeguards necessary to protect the constitutional right to travel articulated in Kent.

For example, does the cumulative necessity for the United States to prevail in the war in Vietnam, to enforce an economic embargo upon Cuba and to maintain a strong NATO alliance in Europe provide sanction for the Department to forbid travel to France on the general ground that President DeGaulle's government is not supporting these American foreign policy goals? Although the advisability of such action might be questionable, feasible arguments exist for its validity under the guidelines advanced in $Z e m e l .53$ Furthermore,

53 Judicial deference to State Department judgment has been most pronounced in the area of sovereign immunity. A suggestion by the Department that a particular litigant be accorded immunity from suit in a pending action will usually be given conclusive effect. See Mexico v. Hoffman, 324 U.S. 30, 35-36 (1945); Rich v. Naviera Vacuba, S.A., 197 F. Supp. 710, 724-26 (E.D. Va.), aff'd per curiam, 295 F.2d 24 (4th Cir. 196I). The sensitive considerations of foreign policy dictating deference to a suggestion of immunity would appear to be equally apposite in regard to travel limitations.

¿3 There is administrative history supporting imposition of this type of restriction. Travel to Hungary was prohibited between December 1949, and May 1951, in order to obtain the release of Robert Vogeler, an imprisoned American citizen, 22 DEP'T State Bull. 398 (1949); Dep't of State Press Release 332, April 28, 1951, and again in December, 195I, in connection with the detention of four American fliers. 26 DEP'T STATE Bulc. 7 (1952). Similar measures were employed against Czechoslovakia in June, 1951, to secure the release of American journalist William Oatis. 24 DEP'T State Bull. 932 (1951). None of these restrictions resulted in litigation. Similarly, there is evidence that the travel ban on Communist China which was upheld in Porter v. Herter, 278 F.2d 280 (D.C. Cir.) (per curiam), cert. denied, 364 U.S. 837 (I960), and Worthy v. Herter, 270 F.2d 905 (D.C. Cir.), cert. denied, 361, U.S. 918 (1959), was imposed hecause of analogous, pohtically coercive motives. See Hearings on the Right to Travel 76.

Zemel also reflects such use of a geographic restriction, for the majority emphasized the need to isolate Cuba in order to insulate the rest of the Western Hemisphere from communist infiltration. However, the majority also pointed out the possible problems that might befall an American citizen traveling in areas of unrest and that might embroil the United States in dangerous international incidents should the President seek to protect the endangered citizen pursuant to 15 Stat. 224 (1868), 22 U.S.C. $\$ 1732$ (1964), note 3 supra. 381 U.S. at 15 .

This discussion presupposes that the Zemel decision is limited to the factual situation before the Court; that is, it only established the constitutionality of the areal restriction on Cuba. It is arguable, however, that the holding was more inclusive and validated the power of the Department to impose any geographic restriction on American travel whenever it deems the need sufficient. If this is the correct interpretation of Zemel, the hypothetical restrictions on travel to France and Saudi Arabia posed in the text and in note 41 supra, respectively, would necessarily be upheld. 
a due process inquiry appears less suitable than a first amendment approach to ascertain and compare the benefits derived by Americans traveling to and in France and the embarrassment resulting from France's lack of cooperation with American policies abroad.

While pursuing a due process analysis in Zemel, the Court assumed that "the Secretary's refusal to validate a passport for a given area acts as a deterrent to travel to that area." 54 Under a first amendment inquiry it would be relevant to consider whether the passport restriction was narrowly drawn to meet the precise evil sought to be proscribed and whether it effectively accomplished that end. ${ }^{55}$ Refusal by the Secretary to validate passports for certain countries has not always in fact prevented travel to those restricted areas $^{56}$ and to Cuba in particular. ${ }^{57}$ Under present legislation and regulations, some of which were upheld by the Court in Zemel, complex problems may arise if the Department seeks to limit all American travel to a given country merely by imposing an areal restriction on issuance of passports.

Suppose that a hypothetical Mr. $C$ desires to travel to Cuba to gain training in effective dissemination of communist propaganda. Under section 215 of the Immigration and Nationality Act of 1952, ${ }^{58}$ a citizen entering or leaving the United States must have a passport.

5. 381 U.S. at 14.

${ }^{55}$ See, e.g., Edwards v. South Carolina, 372 U.S. 229 (1963); Talley v. California, 362 U.S. 60 (1960); Saia v. New York, 334 U.S. 558 (1948); Thornhill v. Alabama, 310 U.S. 88 (1940).

${ }^{50}$ See Hearings on the Right to Travel 94.

${ }^{67}$ See N.Y. Times, July 1, 1963, p. 13, col. 3. Several American students violated the restriction on Cuba by visiting there during the summer of 1963 as guests of Cuban youth groups supporting the Castro government.

ss "(a) When the United States is at war or during the existence of any national emergency proclaimed by the President ... it shall, until otherwise ordered by the President or the Congress, be unlawful ...

"(3) for any person knowingly to make any false statement in an application for permission to depart from or enter the United States with intent to induce or secure the granting of such permission either for himself or for another;

"(b) After such proclamation as is provided for in subsection (a) of this scction has been made and published and while such proclamation is in force, it shall, except as otherwise provided by the President, and subject to such limitations and exceptions as the President may authorize and prescribe, be unlawful for any citizen of the United States to depart from or enter, or attempt to depart from or enter, the United States unless he bears a valid passport.

"(c) Any person who shall willfully violate any of the provisions of this section, or of any order or proclamation of the President promulgated, or of any permit, rule or regulation issued thereunder, shall, upon conviction, be fined not more than $\$ 5,000$, or, if a natural person, imprisoned for not more than five years, or both . . . "66 Stat. 190 (1952), 8 U.S.C. § 1185 (1964). 
The Government also requires that any person seeking a passport must submit an application to the Department relating where he plans to travel and the object of his visit. ${ }^{59}$ Therefore, assuming that Mr. $C$ answers all questions truthfully, his application will probably be denied, for his purpose does not meet the standard prescribed for exceptions to the travel restriction on Cuba. ${ }^{60}$ If $\mathrm{Mr}$. C then departs from the United States without a passport, he will violate Section 215 and seemingly subject himself to the criminal sanctions provided therein.

Suppose instead, however, that Mr. $C$ submits a request for a passport to Hungary to gather information for a proposed book. Under Kent, the passport should be issued, for the sympathies of Mr. $C$ toward communism are immaterial for passport purposes. Further assume that after reaching Hungary, Mr. $C$ proceeds to and enters Cuba. ${ }^{61}$ If the Government can establish that Mr. C knew that he intended to visit Cuba when he filed his passport application, he will be subject to criminal prosecution for making a false statement in his application. ${ }^{62}$ This necessitates proof by the Government of a subjective state of mind. Another possibility would be prosecution for using or attempting to use a passport in violation of the restriction contained therein. ${ }^{63}$ However, Cuba would probably welcome Mr. $C$ and grant him admittance without requiring that he use or attempt to use his passport. ${ }^{64}$ Thus, the resultant criminal proceeding would involve an attempt to prove the semantic intent of Congress in employing the word "use." 65

"Do "Each Application of a Native Citizen for a Passport Must Contain the Following: ... (34) The names of the countries the applicant intends to visit and the object of the visit to each." Exec. Order No. 7854, 3 Fed. Reg. 682 (1938).

${ }^{\circ 0}$ See note 8 supra.

${ }^{01}$ This procedure was followed by the students who violated the restriction on travel to Cuba. See note 57 supra. They first traveled to Czechoslovakia and then proceeded to Cuba where they were welcomed by the Castro government. N.Y. Times, July 1, 1963, p. 13, col. 3. Presently, the Government is prosecuting them in New York as violators of $\S 215$, note 58 supra. Letter from Frederick Smith, Jr., Department of State, to the Duke Law Journal, Oct. 13, 1965.

o2 18 U.S.C. § 1542 (1964). The Government might also prosecute under $\S 215$ of the Immigration and Nationality Act, 66 Stat. 190 (1952), 8 U.S.C. $§ 1185$ (1964); see note 58 supra.

${ }^{03} 18$ U.S.C. 1544 (1964) provides, ". . whoever willfully and knowingly uses or attempts to use any passport in violation of the conditions or restrictions therein contained, or of the rules prescribed pursuant to the laws regulating the issuance of passports ... shall be fined not more than $\$ 2,000$ or imprisoned not more than five years, or both."

"s See Hearings on the Right to Travel 91-95.

${ }^{o r}$ Aside from debating whether Mr. $C$ "used" his passport to go to Cuba, one could 
The only other official alternative available to the Department to punish Mr. $C$ for violating the restriction is revocation of his passport. If the Department declares his passport totally void, ${ }^{40}$ Mr. $C$ will violate Section 215 by returning to the United States without a passport. However, it has been held that a citizen cannot be precluded from returning to his homeland. ${ }^{07}$ If instead, the Secretary were to invalidate his passport, excepting only travel back to the United States, and order him to return home at once, ${ }^{08}$ there would ostensibly be no compelling legal reason for Mr. $C$ to obey. There are no means provided for enforcing the Department's order, and Mr. $C$ can gain readmittance to the United States whenever he desires. $^{69}$ Furthermore, he could visit countries other than Cuba which would be similarly disposed to grant him entrance, and it is questionable whether his action could be construed as constituting sufficient grounds for expatriation. ${ }^{70}$ Thus, the right of all Ameri-

argue that he used it in leaving this country or in traveling to and in Hungary and that such action constituted "use" within the meaning of the statute.

${ }^{B C}$ The Department could declare the passport void due to the violation of the restriction contained within the passport. Exec. Order No. 7856, 3 Fed. Reg. 687 (1938), note 3 supra.

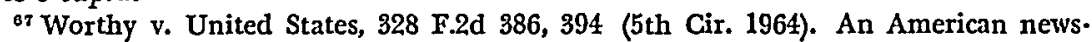
paperman violated the passport restriction upon travel to Communist China and Hungary. Subsequently, when he applied to have his passport renewed, the Department declared that renewal would be approved only if he agreed to abide by the restrictions contained therein. The Department's position was upheld in Worthy v. Herter, 270 F.2d 905 (D.C. Cir.), cert. denied, 361 U.S. 918 (1959). Thereafter, he traveled to Cuba and prepared to travel to Communist China. The State Department declared his passport void. When he returned to this country, he was arrested and charged with entering the United States without a valid passport in time of a declared national emergency. Worthy v. United States, supra at 389 . In the subsequent criminal proceeding under $\$ 215$, the Court held that an American citizen has a right to return to the United States without being subject to criminal penalties for re-entry, even if he does not possess a valid passport. Id. at 394.

${ }^{\circ 8}$ The Department's authority to invalidate a passport in this manner is based on Exec. Order No. 7896, 3 Fed. Reg. 687 (1938). A serious problem arises from the line of cases culminating in Kent and Aptheker, however. Before the Department can invalidate a passport, it must see that both procedural and substantive due process are present. See notes 15 and 16 supra and accompanying text. Thus the Department is probably required to establish a makeshift Board of Passport Appeals in the foreign port in which the passport-holder is located in order to review the reasons for the revocation and to afford the holder an opportunity to be confronted by the evidence and offer whatever explanation he might have. Establishment of such a quasi-Board might be difficult in Cuba or Red China.

${ }^{\circ 0}$ Worthy v. United States, 328 F.2d 386, 394 (5th Cir. 1964); see note 67 supra.

${ }^{70}$ In Perkins v. Elg, 307 U.S. 325, 334 (1939), the Supreme Court held that expatriation can be accomplished only by voluntary action on the part of a citizen in the absence of a statute or treaty having that effect. See generally Schneider v. Rusk, 377 U.S. 163 (1964) (continuous three year residence in foreign state of previous citizenship not grounds for expatriation); Kennedy v. Mendoza-Martinez, 372 U.S. 
cans to travel abroad and gather information has been limited in favor of a passport restriction which upon analysis may be somewhat less than effective in accomplishing one of its goals, isolation of Cuba to prevent training of communist organizers there.

The need for new legislation containing more definitive congressional guidelines for denying, limiting and revoking passports is apparent. A finding that the 1926 act incorporates prior administrative practices appears inadequate both as a safeguard to the right to travel and as a means to facilitate the Government's foreigu policy objectives. Furthermore, the emerging body of law dealing with the permissible scope of passport restrictions and the involvement of peripheral first amendment freedoms in the right to travel seemed to be taking a determinative direction after Kent and Aptheker, but now appears uncertain. Zemel raises the possibility that each new travel limitation may have to be tested by expensive, time-consuming litigation which may not afford a citizen's right to travel adequate constitutional protection.

144 (1963) (travel abroad to evade the military draft is not sufficient for expatriation); Perez v. Brownell, 356 U.S. 44 (1958) (upholding forfeiture of citizenship for voting in a foreign election). 